\title{
CARDIOMETABOLIC RISK AMONG MONTENEGRIN URBAN CHILDREN IN RELATION TO OBESITY AND GENDER
}

\author{
Milica Martinović ${ }^{1}$, Goran Belojević ${ }^{2}$, Marina Jakšić ${ }^{3}$, Nebojša Kavarić ${ }^{4}$ and Aleksandra Klisić ${ }^{4}$ \\ ${ }^{1}$ Faculty of Medicine, Department of Pathophysiology and Laboratory Medicine, \\ University of Montenegro, Podgorica, Montenegro; \\ ${ }^{2}$ Faculty of Medicine, Institute of Hygiene and Medical Ecology, University of Belgrade, Belgrade, Serbia; \\ ${ }^{3}$ Institute for Children's Diseases, Department of Laboratory Diagnostics, Podgorica, Montenegro; \\ ${ }^{4}$ Primary Health Care Centre, Podgorica, Montenegro
}

\begin{abstract}
SUMMARY - Considering previously reported discrepant results in the literature, we aimed to investigate the impact of gender and overweight/obesity on cardiometabolic risk (CMR) among Montenegrin urban children. The cross-sectional study included random sample of 201 schoolchildren aged 7-12 years (64\% of boys) from Podgorica. Children's nutritional status was determined according to the International Obesity Task Force criteria. CMR was assessed using a sum of $\mathrm{z}$ values of the following five indicators: glucose, total cholesterol, inverted value of high-density lipoprotein cholesterol, triglycerides, and hypertension. Higher CMR was found among both overweight and obese boys compared to normal weight boys ( $\mathrm{p}<0.001)$. The effect size of the difference in CMR between overweight and obese girls and normal weight counterparts was less prominent $(\mathrm{p}<0.05)$. Logistic regression analysis revealed that body mass index was independent predictor of high CMR [odds ratio $(\mathrm{OR})=1.06 ; 95 \%$ confidence interval $(\mathrm{CI})=1.02-1.10) ; \mathrm{p}=0.002]$. On the contrary, we found no impact of socioeconomic status, physical activity or sedentary time on CMR in the examined cohort of schoolchildren. In conclusion, both overweight and obesity even among young population are related to higher CMR and this effect is more prominent among boys as compared to girls.
\end{abstract}

Key words: Cardiometabolic risk; Childhood obesity; Hypertension; Metabolic syndrome

\section{Introduction}

Obesity is a global public health problem ${ }^{1}$ with an ever-increasing prevalence both among children and adults over the past decade ${ }^{2}$.This is also a public health concern in Montenegro since the prevalence of childhood overweight and obesity $(\mathrm{OOb})$ is reported to be $22.9 \%$ and $5.3 \%$, respectively ${ }^{3}$.

Obesity is a risk factor for many disorders such as metabolic syndrome, type 2 diabetes mellitus, cardio-

Correspondence to: Aleksandra Klisic, $M D, P b D$, Primary Health Care Center, Trg Nikole Kovačevića 6, 81000 Podgorica, Montenegro

E-mail: aleksandranklisic@gmail.com

Received June 12, 2018, accepted July 12, 2018 vascular disease, cancer, psychosocial and neurocognitive distress ${ }^{4-6}$. Childhood and adulthood obesity are related and there is evidence that even $80 \%$ of obese children continue to be obese later in life, which is often accompanied with an increased cardiometabolic risk $(\mathrm{CMR})^{7}$. Therefore, of utmost public health interest is to deeply investigate the underlying mechanisms of increased CMR among young population ${ }^{8}$.

Although previous studies confirmed the relationship between childhood obesity and $\mathrm{CMR}^{9-13}$, it is still unclear whether this relationship also exists in overweight children, since some studies did not find difference in CMR between overweight and normal weight children ${ }^{14}$. Additionally, controversial results were shown with regard to gender, reporting no difference between 
obese boys and girls ${ }^{15}$, either with higher CMR among obese boys compared to obese girls ${ }^{16}$, or vice vers $a^{17}$.

In this study, we hypothesized on CMR to be higher among overweight children compared to normal weight children, and on the existence of gender differences with regard to CMR. Therefore, considering previously reported opposite results on this issue, we aimed to investigate the effect of gender and $\mathrm{OOb}$ on $\mathrm{CMR}$ among Montenegrin urban schoolchildren aged 7-12 years.

\section{Material and Methods}

\section{Study population}

The sample in this cross-sectional study comprised 201 children aged $7-12$ years [i.e., 128 boys (64\%) and 73 girls (36\%)], randomly chosen from ten elementary schools from Podgorica, Montenegro within a representative national sample of children ${ }^{3}$. According to their nutritional status based on the International Obesity Task Force (IOTF) criteria ${ }^{18,19}$, the children were grouped into three subgroups, as follows: normal weight $(n=85 / 42.3 \%)$, overweight $(n=81 / 40.3 \%)$ and obese ( $n=35 / 17.4 \%)$.

Exclusion criteria were underweight children, those with endocrine and metabolic disorders (secondary obesity), chronic diseases, usage of medicines leading to metabolic disturbances (e.g., corticosteroids), and those who were not willing to participate in the examination.

The study was approved by the Ethics Committee of the Faculty of Medicine, University of Montenegro. Parents and children gave their informed consent to participate in the study, and the research was conducted according to the Declaration of Helsinki.

\section{Questionnaire}

Children's parents were asked to assess their socioeconomic status as low (income insufficient for basic needs); medium (sufficient); or high (more than sufficient). Children's sedentary time was assessed by the number of hours daily watching TV, and physical activity by the number of days in a week with at least one hour of activity out of school.

\section{Anthropometric measurements}

Children were weighed on a digital scale accurate to $0.1 \mathrm{~kg}$ (SECA, model SE 808; Hamburg, Germany). A stadiometer accurate to $0.5 \mathrm{~cm}$ (GIMA, code
27328; Gessate, Milan, Italy) was used to measure body height. Body mass index (BMI) percentile for age and gender was calculated using software available on the Center for Disease Control and Prevention website (https://www.cdc.gov/healthyweight/assessing/bmi/childrens_bmi/tool_for_schools.html).

Body composition (total fat percent, muscle mass, fat free mass, total body water percent) was determined with a bioelectric impedance device (Tanita BC-418, Japan). Children's nutritional status was evaluated according to the IOTF criteria $^{18,19}$. IOTF provides BMI cut-off points by age and sex for thinness, overweight and obesity for children and adolescents aged 2-18 years. The cut-off points correspond to adult BMI, as follows: $16.5 \mathrm{~kg} / \mathrm{m}^{2}$ (thinness grade 1 ); $17 \mathrm{~kg} / \mathrm{m}^{2}$ (thinness grade 2); $18.5 \mathrm{~kg} / \mathrm{m}^{2}$ (thinness grade 3 ); $25 \mathrm{~kg} / \mathrm{m}^{2}$ (overweight); and $30 \mathrm{~kg} / \mathrm{m}^{2}$ (obesity).

\section{Blood pressure measurement}

Blood pressure was measured with an Omron HEM 907 XL oscillometric monitor. The measurements were performed according to standardized methodology $\mathrm{y}^{20}$ in sitting position on a non-dominant arm, after 5 -minute rest, between noon and 3:00 p.m. in a quiet room in school. Diagnostic criterion for hypertension was systolic blood pressure (SBP) and/or diastolic blood pressure (DBP) equal or exceeding $95^{\text {th }}$ percentile of values according to body height, sex and age ${ }^{20}$.

\section{Biochemical analyses}

Blood samples were obtained in the morning, after 8-hour overnight fast, in the Center of Laboratory Diagnostics, Primary Health Care Center in Podgorica. After being left to clot for 30 minutes and then centrifuged, serum samples were analyzed for several biochemical parameters [i.e., fasting glucose, total cholesterol (TC), low-density lipoprotein cholesterol (LDLc), high-density lipoprotein cholesterol (HDL-c) and triglycerides (TG)], using routine procedures with spectrophotometric method (Roche Cobas c501, Mannheim, Germany).

\section{$Z$ values and cardiometabolic risk}

$Z$ value represents a measure of how many standard deviations a raw score is below or above the population mean. A child's total CMR is a sum of $z$ values of blood glucose, TG, inverted HDL-c (1 - HDL-c; 
Table 1. Anthropometric indicators in relation to nutritional status of investigated schoolchildren aged 7-12 from Podgorica

\begin{tabular}{|c|c|c|c|c|}
\hline \multirow[b]{2}{*}{ Anthropometric indicator } & \multicolumn{3}{|c|}{ Nutritional status } & \multirow[b]{2}{*}{$\mathrm{p}^{\#}$} \\
\hline & $\begin{array}{l}\text { Obese } \\
\mathrm{N}=35\end{array}$ & $\begin{array}{l}\text { Overweight } \\
\mathrm{N}=81\end{array}$ & $\begin{array}{l}\text { Normal weight } \\
\mathrm{N}=85\end{array}$ & \\
\hline Total percentage of fat (\%) & $29.9 \pm 7.1^{*}$ & $26.1 \pm 6.8^{* *}$ & $15.7 \pm 5.0$ & $<0.001$ \\
\hline Muscle mass $(\mathrm{kg})$ & $41.0 \pm 10.0^{*}$ & $36.8 \pm 7.5^{* *}$ & $29.4 \pm 6.5$ & $<0.001$ \\
\hline Fat free mass $(\mathrm{kg})$ & $43.2 \pm 10.5^{*}$ & $38.8 \pm 7.9^{* *}$ & $30.9 \pm 6.8$ & $<0.001$ \\
\hline Total body water percentage (\%) & $51.1 \pm 5.2^{*}$ & $54.1 \pm 4.9^{* *}$ & $61.7 \pm 3.7$ & $<0.001$ \\
\hline Body mass index percentile & $97.7 \pm 9.4^{* * *}$ & $90.4 \pm 7.7^{* *}$ & $43.6 \pm 21.1$ & $<0.001$ \\
\hline
\end{tabular}

${ }^{*}$ ANOVA; ${ }^{*}<0.01$ vs. overweight (LSD post hoc test); ${ }^{* *}<0.001$ vs. normal weight (LSD post hoc test); ${ }^{* * *}<0.05$ vs. overweight (LSD post hoc test)

Table 2. Biochemical parameters, blood pressure and total cardiometabolic risk (CMR)* among boys aged 7-12 years from Podgorica according to nutritional status

\begin{tabular}{|c|c|c|c|c|}
\hline \multirow{2}{*}{ Parameter } & Obese & Overweight & Normal weight & \multirow[b]{2}{*}{$\mathrm{p}$} \\
\hline & $(\mathrm{N}=25)$ & $(\mathrm{N}=49)$ & $(\mathrm{N}=54)$ & \\
\hline Glucose (mmol/L) & $5.37 \pm 0.37^{s}$ & $5.38 \pm 0.36^{\ddagger}$ & $5.16 \pm 0.42$ & $0.007^{\#}$ \\
\hline $\mathrm{TG}(\mathrm{mmol} / \mathrm{L}) / \operatorname{median}(\mathrm{Q} 1-\mathrm{Q} 3) /$ & $\begin{array}{l}0.74^{\# \#} \\
(0.63-1.06)\end{array}$ & $\begin{array}{l}0.86^{\text {ss }} \\
(0.55-1.31)\end{array}$ & $\begin{array}{l}0.60 \\
(0.45-0.83)\end{array}$ & $<0.01^{* *}$ \\
\hline LDL-c (mmol/L) & $2.77 \pm 0.80$ & $2.65 \pm 0.77$ & $2.39 \pm 0.64$ & $0.061^{\#}$ \\
\hline HDL-c (mmol/L) & $1.39 \pm 0.40^{\ddagger}$ & $1.45 \pm 0.36^{\ddagger}$ & $1.68 \pm 0.40$ & $0.002^{\#}$ \\
\hline $\mathrm{TC}(\mathrm{mmol} / \mathrm{L})$ & $4.38 \pm 0.88$ & $4.43 \pm 0.88$ & $4.23 \pm 0.80$ & $0.457^{\#}$ \\
\hline $\mathrm{SBP}(\mathrm{mm} \mathrm{Hg})$ & $122.4 \pm 9.9^{\wedge}$ & $112.1 \pm 11.1$ & $108.0 \pm 11.8$ & $<0.001^{\#}$ \\
\hline $\mathrm{DBP}(\mathrm{mm} \mathrm{Hg})$ & $77.0 \pm 11.4^{\wedge}$ & $68.3 \pm 9.5$ & $64.8 \pm 8.7$ & $<0.001^{\#}$ \\
\hline Hypertension (n/\%) & $14 / 56$ & $13 / 29$ & $13 / 25$ & $0.02^{\#}$ \\
\hline CMR*/median (Q1-Q3)/ & $\begin{array}{l}0.76^{\$ s} \\
(-0.35-2.66)\end{array}$ & $\begin{array}{l}0.65^{\$ s} \\
(-0.83-1.79)\end{array}$ & \begin{tabular}{|l}
-1.49 \\
$(-2.56-0.41)$
\end{tabular} & $<0.001^{* *}$ \\
\hline
\end{tabular}

$\mathrm{TG}=$ triglycerides; LDL-c = low-density lipoprotein cholesterol; HDL-c = high-density lipoprotein cholesterol; TC = total cholesterol; SBP = systolic blood pressure; DBP = diastolic blood pressure; CMR = cardiometabolic risk *sum of z-values of glucose, TG, an inverted HDL-c, TC and hypertension; ${ }^{*}$ ANOVA; ${ }^{\$}<0.05$ vs. normal weight (LSD post hoc test); ${ }^{\ddagger}<0.01$ vs. normal weight (LSD post hoc test); ${ }^{\wedge}<0.001$ vs. normal weight (LSD post hoc test); ${ }^{* * K r u s k a l-W a l l i s ~ t e s t ~ b y ~ r a n k s ; ~}{ }^{* \#<}<0.05$ vs. normal weight (Mann Whitney U test); ${ }^{\$ \$}<0.001$ vs. normal weight (Mann Whitney U test); ${ }^{\neq \ddagger} \chi^{2}$-test $=7.85 ; p=0.02$

to keep the same direction of values as for other indicators), TC and hypertension. A cut-off value for total CMR was obtained by adding one standard deviation to the mean value of CMR for the sample of children examined. A single-factor model underlying the metabolic syndrome in children using $\mathrm{z}$ statistics and one standard deviation from mean $\mathrm{z}$ as a cut-off value was valid after factor analysis ${ }^{15}$.

\section{Statistical analysis}

Kolmogorov-Smirnov normality test was used to check the distribution of variables. We used the ANO-
VA and LSD post-hoc test (normal distribution) or Kruskal-Wallis test by ranks and Mann-Whitney U test post-hoc (not normal distribution) to compare the means of biochemical parameters and total CMR scores in the three subgroups of children. The $\chi^{2}$-test was applied to compare the percentage of children with hypertension in the three subgroups. Logistic regression analysis was applied to test the association between CMR and other variables in order to reveal independent predictors of high CMR. The probability of alpha error lower than 5\% was accepted as the level of significance $(\mathrm{p}<0.05)$. 
Table 3. Biochemical parameters, blood pressure and total cardiometabolic risk (CMR)* among girls aged 7-12 years from Podgorica according to nutritional status

\begin{tabular}{|c|c|c|c|c|}
\hline \multirow{2}{*}{ Parameter } & Obese & Overweight & Normal weight & \multirow[b]{2}{*}{$\mathrm{p}$} \\
\hline & $(\mathrm{N}=10)$ & $(\mathrm{N}=32)$ & $(\mathrm{N}=31)$ & \\
\hline Glucose $(\mathrm{mmol} / \mathrm{L})$ & $5.32 \pm 0.33$ & $5.34 \pm 0.99^{\$}$ & $4.95 \pm 0.39$ & $0.080^{\#}$ \\
\hline $\mathrm{TG}(\mathrm{mmol} / \mathrm{L}) /$ median $(\mathrm{Q} 1-\mathrm{Q} 3) /$ & $\begin{array}{l}0.94 \\
(0.53-1.40)\end{array}$ & $\begin{array}{l}0.85^{\wedge} \\
(0.59-1.18)\end{array}$ & $\begin{array}{l}0.58 \\
(0.52-0.81)\end{array}$ & $0.033^{\ddagger}$ \\
\hline LDL-c (mmol/L) & $2.88 \pm 0.74$ & $2.51 \pm 0.71$ & $2.49 \pm 0.84$ & $0.355^{\#}$ \\
\hline HDL-c (mmol/L) & $1.49 \pm 0.42$ & $1.33 \pm 0.36^{* *}$ & $1.63 \pm 0.39$ & $0.009^{\#}$ \\
\hline $\mathrm{TC}(\mathrm{mmol} / \mathrm{L})$ & $4.61 \pm 0.73$ & $4.27 \pm 1.01$ & $4.33 \pm 0.91$ & $0.602^{\#}$ \\
\hline $\mathrm{SBP}(\mathrm{mm} \mathrm{Hg})$ & $120.5 \pm 16.5^{\S}$ & $119.7 \pm 13.7^{* *}$ & $109.9 \pm 10.8$ & $0.011^{\#}$ \\
\hline $\mathrm{DBP}(\mathrm{mm} \mathrm{Hg})$ & $72.5 \pm 11.2$ & $72.0 \pm 7.9$ & $68.0 \pm 9.0$ & $0.184^{\#}$ \\
\hline Hypertension (n/\%) & $5 / 50$ & $10 / 36$ & $8 / 28$ & $0.43^{\# \#}$ \\
\hline CMR*/median (Q1-Q3)/ & $\begin{array}{l}2.12^{\$ s} \\
(-2.08-3.68)\end{array}$ & $\begin{array}{l}-0.40^{\ddagger} \\
(-1.52-1.51)\end{array}$ & $\begin{array}{l}-1.23 \\
(-2.70-0.13)\end{array}$ & $0.019^{\ddagger}$ \\
\hline
\end{tabular}

TG = triglycerides; LDL-c = low-density lipoprotein cholesterol; HDL-c = high-density lipoprotein cholesterol; $\mathrm{TC}=$ total cholesterol; $\mathrm{SBP}=$ systolic blood pressure; $\mathrm{DBP}=$ diastolic blood pressure; $\mathrm{CMR}=$ cardiometabolic risk *sum of $\mathrm{z}$-values of plasma glucose, TG, an inverted HDL, TC and hypertension; \#ANOVA; ${ }^{\$}<0.05$ vs. normal weight (LSD post hoc test); ${ }^{\ddagger}$ Kruskal-Wallis test by ranks; $\wedge<0.01$ (Mann Whitney U test); ${ }^{* *}<0.01$ vs. normal weight (LSD post hoc test); ${ }^{\#}$ Pearson $\chi^{2}=1.70 ; \mathrm{p}=0.43 ;{ }^{\$ s}<0.05$ Mann Whitney $\mathrm{U}$ test; ${ }^{\ddagger}<0.001$ Mann Whitney $U$ test

Table 4. Factors influencing cardiometabolic risk among schoolchildren aged 7-12 years from Podgorica (univariate logistic regression analysis)

\begin{tabular}{|l|l|l|l|}
\hline Factor & OR & $95 \%$ CI & p \\
\hline Gender (male=1; female=2) & 1.30 & $0.57-3.00$ & 0.536 \\
Age (per month) & 1.00 & $0.76-1.31$ & 1.000 \\
$\begin{array}{l}\text { Socioeconomic status } \\
\text { (1=low; 2=medium; 3=high) }\end{array}$ & 1.11 & $0.51-2.44$ & 0.788 \\
$\begin{array}{l}\text { Physical activity out of } \\
\text { school (per day in a week) }\end{array}$ & 1.20 & $0.91-1.60$ & 0.197 \\
$\begin{array}{l}\text { Watching TV (per hour } \\
\text { daily) }\end{array}$ & 0.85 & $0.59-1.23$ & 0.395 \\
Body mass index percentile & 1.06 & $1.02-1.10$ & 0.002 \\
\hline
\end{tabular}

\section{Results}

Overweight and obese children had a significantly higher total fat percentage, free fat mass, muscle mass, lower total water percentage and BMI percentile compared to normal weight children (Table 1).

Moreover, significantly higher glucose and TG, but lower HDL-c was found in OOb boys compared to normal weight boys (Table 2).

The SBP and DBP parameters, as well as the percentage of children with hypertension also were sig- nificantly higher among $\mathrm{OOb}$ boys compared to normal weight counterparts (Table 2). Similarly, significantly higher glucose, TG and SBP, as well as lower HDL-c were found among $\mathrm{OOb}$ girls compared to normal weight girls (Table 3).

Overall, $\mathrm{CMR}$ was significantly higher among $\mathrm{OOb}$ boys and girls compared to normal weight counterparts. However, the effect size was larger among boys compared to girls (Tables 2 and 3). Logistic regression analysis showed that BMI percentile significantly influenced CMR in the study children (Table 4). On the other hand, we found no association between socioeconomic status, physical activity or watching TV and CMR in the study cohort of schoolchildren (Table 4).

\section{Discussion}

The findings of the current study showed that both overweight and obese children were at a higher CMR compared to normal weight counterparts. However, the effect size of $\mathrm{OOb}-\mathrm{CMR}$ relationship was larger among boys compared to girls.

We have previously reported on the association between obesity and increased CMR in adolescent girls aged 16-19 years ${ }^{21,22}$. Herein, we confirmed such a relationship even at a much younger age. 
Our findings on the early development of CMR factors among obese schoolchildren are concordant with numerous other studies ${ }^{16,23,24}$. In children with severe obesity, a metabolic syndrome is very likely. Results of a study on preadolescent children from New Zealand suggest that not a single, but rather a group of factors may influence cardiometabolic health (e.g., high blood pressure, BMI, and cholesterol ${ }^{25}$.

Hypertrophied adipose tissue is a great source of reactive oxygen species (ROS), as well as proinflammatory cytokines (e.g., monocyte chemoattractant protein-1, tumor necrosis factor-alpha, interleukin-6) and adipokines (e.g., leptin, retinol-binding protein 4, apelin, resistin), which represents the state of increased oxidative stress and low-grade inflammation in obesity $\mathrm{t}^{4,5,21,22}$. On the other hand, lower level of the antioxidant defense system, as well as adipokine adiponectin which has anti-inflammatory and cardioprotective effects in the obese state is recorded ${ }^{5,22}$. The ROS further stimulate increased expression of cytokines, growth factors, and adhesion molecules, which may lead to many pathophysiological consequences such as insulin resistance, dyslipidemia, hypertension, hypercoagulable state, thus increasing $\mathrm{CMR}^{5}$.

Similar to our results, studies on Brazilian schoolchildren $^{23}$ and Chilean adolescents ${ }^{26}$ showed a larger effect size of obesity on CMR among boys compared to girls. In a Korean National Health and Nutrition Examination Survey, a higher prevalence of metabolic syndrome indicators such as hypertension and hyperglycemia was also found among boys in comparison to girls ${ }^{27}$. However, a higher CMR was recorded among obese girls in comparison to obese boys in eight European countries ${ }^{17}$. On the other hand, Martínez-Vizcaíno et al. found no difference in CMR between obese boys and girls aged 10-13 years from Spain ${ }^{15}$. The prevalence of metabolic syndrome was also similar between obese boys and girls aged 7-18 in a national school-based surveillance program in $\operatorname{Iran}^{28}$. The possible explanation for so many discordant findings might be in different sample size of examined cohorts.

Our finding of a significant relationship between $\mathrm{BMI}$ and CMR is congruent with the results of other studies $^{21,29}$. On the other hand, we did not find any impact of socioeconomic status of children on their CMR. In an earlier study on Colombian children aged 6-10 years, socioeconomic status was positively related to obesity and insulin resistance ${ }^{30}$. Contrary to these findings, $72 \%$ higher odds for metabolic syndrome was found among low socioeconomic status children in Iran compared to those with a high economic status, which was explained by unhealthy eating habits ${ }^{31}$. However, in a recent longitudinal study on UK children, obesity and metabolic disturbances were not related to deprivation, which is similar to our results showing that children from all backgrounds may be vulnerable to obesogenic environments ${ }^{32}$.

Furthermore, we did not observe any relationship of children's sedentary time and physical activity out of school with CMR. In a recent prospective study on 10-year-old children, it was shown that moderate-tovigorous physical activity, but not sedentary time was related to elevated $\mathrm{CMR}^{33}$. It seems that dietary habits, but not physical inactivity may explain the obesityCMR relationship in our investigation.

The most effective approaches in lowering childhood CMR are increased physical activity and weight $\operatorname{loss}^{34}$. Even a modest reduction in BMI z-score after one year of a joint hospital/public health nurse intervention may significantly lower children's $\mathrm{CMR}^{34}$. Another study on overweight and obese children and adolescents showed that a 1-year lifestyle intervention lowered their CMR by decreasing cardiometabolic risk factors. These effects were similar in children with overweight, obesity, or morbid obesity ${ }^{35}$.

It is important to emphasize that the cross-sectional design of our current study was a limitation of this research. Therefore, longitudinal studies are needed to confirm the causal relationship among examined cardiometabolic risk factors in young population.

\section{Conclusion}

We showed that both overweight and obesity in childhood were related to higher CMR and this relationship was more pronounced among boys compared to girls. BMI significantly influenced CMR, whereas socioeconomic status, physical activity or sedentary time were not associated with CMR in schoolchildren. Prevention of cardiovascular diseases should start early in childhood by focusing on overweight/obese children.

\section{Acknowledgment}

The study was financially supported by the Montenegrin Ministry of Science, Contract No. 1366 /2012. 


\section{References}

1. Chung A, Backholer K, Wong E, Palermo C, Keating C, Peeters A. Trends in child and adolescent obesity prevalence according to socioeconomic position: protocol for a systematic review. Syst Rev. 2014;3:52. doi: 10.1186/2046-4053-3-52

2. Williams EP, Mesidor M, Winters K, Dubbert PM, Wyatt SB. Overweight and obesity: prevalence, consequences, and causes of a growing public health problem. Curr Obes Rep. 2015; 4(3):363-70. doi: 10.1007/s13679-015-0169-4

3. Martinovic M, Belojevic G, Evans G, Lausevic D, Asanin B, Samardzic M, et al. Prevalence of and contributing factors for overweight and obesity among Montenegrin schoolchildren. Eur J Public Health. 2015;25:833-9. doi: 10.1093/eurpub/ ckv071

4. Al-Hamad D, Raman V. Metabolic syndrome in children and adolescents. Transl Pediatr. 2017;6:397-407. doi: 10.21037/ tp.2017.10.02

5. Marseglia L, Manti S, D’Angelo G, Nicotera A, Parisi E, Di Rosa $G$, et al. Oxidative stress in obesity: a critical component in human diseases. Int J Mol Sci. 2014;16:378-400. doi: 10.3390/ijms16010378

6. Yanovski JA. Pediatric obesity. An introduction. Appetite. 2015;93:3-12. doi: 10.1016/j.appet.2015.03.028

7. Schwartz SM (Chief Editor: Bhatia J.) Obesity in Children. Medscape, 2017. www. emedicine.medscape.com/article/ 985333-overview. (accessed March 2018)

8. Weber DR, Leonard MB, Zemel BS. Body composition analysis in the pediatric population. Pediatr Endocrinol Rev. 2012;10:130-9. PMID: 23469390

9. Nadeau KJ, Maahs DM, Daniels SR, Eckel RH. Childhood obesity and cardiovascular disease: links and prevention strategies. Nat Rev Cardiol. 2011;8:513-25. doi: 10.1038/nrcardio. 2011.86

10. Cook S, Kavey RE. Dyslipidemia and pediatric obesity. Pediatr Clin North Am. 2011;58:1363-73. doi: 10.1016/j.pcl.2011. 09.003

11. Rakočević L, Rakočević V. Incidence of cardiovascular risk factors in obese children. Acta Clin Croat. 2016;55:407-13. doi: 10.20471/acc.2016.55.03.09

12. Lauer RM, Lee J, Clarke WR. Factors affecting the relationship between childhood and adult cholesterol levels: the Muscatine Study. Pediatrics. 1988;82:309-18. PMID: 3405659

13. Brady TM. Obesity-related hypertension in children. Front Pediatr. 2017;5:197. doi: 10.3389/fped.2017.00197

14. Kelly AS, Barlow SE, Rao G, Inge TH, Hayman LL, Steinberger J, et al. Severe obesity in children and adolescents: identification, associated health risks, and treatment approaches: a scientific statement from the American Heart Association. Circulation. 2013;128:1689-712. doi: 10.1161/CIR.0b013e $3182 \mathrm{a} 5 \mathrm{cfb} 3$

15. Martínez-Vizcaíno V, Martínez MS, Aguilar FS, Martínez SS, Gutiérrez RF, López MS, et al. Validity of a single-factor mod- el underlying the metabolic syndrome in children: a confirmatory factor analysis. Diabetes Care. 2010;33:1370-2. doi: $10.2337 / \mathrm{dc} 09-2049$

16. Burgos MS, Reuter CP, Possuelo LG, Valim AR, Renner JD, Tornquist L, et al. Obesity parameters as predictors of early development of cardiometabolic risk factors. Cien Saude Colet. 2015;20:2381-8. doi: 10.1590/1413-81232015208.11672014

17. Ahrens W, Moreno LA, Mårild S, Molnár D, Siani A, De Henauw S. Metabolic syndrome in young children: definitions and results of the IDEFICS study. Int J Obes (Lond). 2014;38 Suppl 2:S4-S14. doi: 10.1038/ijo.2014.130

18. Cole TJ, Bellizzi MC, Flegal KM, Dietz WH. Establishing a standard definition for child overweight and obesity worldwide: international survey. BMJ. 2000;320:1240-3. PMID: 10797032

19. Cole TJ, Lobstein T. Extended international (IOTF) body mass index cut-offs for thinness, overweight and obesity. Pediatr Obes. 2012;7:284-94. doi: 10.1111/j.2047-6310.2012.00064.x

20. U.S. Department of Health and Human Services. The Fourth Report on the Diagnosis, Evaluation, and Treatment of High Blood Pressure in Children and Adolescents. Bethesda MD: National Institutes of Health National Heart, Lung, and Blood Institute, NIH Publication No. 05-5267, 2004. https://www. nhlbi.nih.gov/files/docs/resources/heart/hbp_ped.pdf

21. Klisic A, Kavaric N, Bjelakovic B, Soldatovic I, Martinovic M, Kotur-Stevuljevic J. The association between retinol-binding protein 4 and cardiovascular risk score is mediated by waist circumference in overweight/obese adolescent girls. Acta Clin Croat. 2017;56:92-8. doi: 10.20471/acc.2017.56.01.14

22. Klisic A, Kavaric N, Soldatovic I, Bjelakovic B, Kotur-Stevuljevic J. Relationship between cardiovascular risk score and traditional and nontraditional cardiometabolic parameters in obese adolescent girls. J Med Biochem. 2016;35(3):282-92. doi: 10.1515/jomb-2016-0005

23. Alvarez MM, Vieira AC, Moura AS, da Veiga GV. Insulin resistance in Brazilian adolescent girls: association with overweight and metabolic disorders. Diabetes Res Clin Pract. 2006;74:183-8. doi: 10.1016/j.diabres.2006.03.018

24. Jago R, Mendoza JA, Chen T, Baranowski T. Longitudinal associations between BMI, waist circumference and cardiometabolic risk in US youth: monitoring implications. Obesity (Silver Spring). 2013;21:E271-9. doi: 10.1002/oby.20080

25. Stoner L, Weatherall M, Skidmore P, Castro N, Lark S, Faulkner J. Cardiometabolic risk variables in preadolescent children: a factor analysis. J Am Heart Assoc. 2017;6(10): e007071. doi: 10.1161/JAHA.117.007071

26. Pacheco LS, Blanco E, Burrows R, Reyes M, Lozoff B, Gahagan S. Early onset obesity and risk of metabolic syndrome among Chilean adolescents. Prev Chronic Dis. 2017;14:E93. doi: $10.5888 / \operatorname{pcd} 14.170132$

27. Seo JY, Kim JH. Validation of surrogate markers for metabolic syndrome and cardiometabolic risk factor clustering in children and adolescents: a nationwide population-based study. PLoS ONE. 2017;12:e0186050. doi: 10.1371/journal.pone.0186050 
28. Heshmat R, Heidari M, Ejtahed HS, Motlagh ME, MahdaviGorab A, Ziaodini H. Validity of a continuous metabolic syndrome score as an index for modeling metabolic syndrome in children and adolescents: the CASPIAN-V study. Diabetol Metab Syndr. 2017;9:89. doi: 10.1186/s13098-017-0291-4

29. Quadros TMB, Gordia AP, Silva LR. Anthropometry and clustered cardiometabolic risk factors in young people: a systematic review. Rev Paul Pediatr. 2017;35:340-50. doi: 10.1590/1984-0462/;2017;35;3;00013

30. Buitrago-Lopez A, van den Hooven EH, Rueda-Clausen CF, Serrano N, Ruiz AJ, Pereira MA, et al. Socioeconomic status is positively associated with measures of adiposity and insulin resistance, but inversely associated with dyslipidaemia in Colombian children. J Epidemiol Community Health. 2015;69: 580-7. doi: 10.1136/jech-2014-204992

31. Gharipour M, Sadeghi M, Nouri F, Nezafati P, Qader SS, Taheri M. Socioeconomic determinants and metabolic syndrome: results from the Isfahan Healthy Heart Program. Acta Biomed. 2017;87:291-8. PMID: 28112697

32. Voss LD, Hosking J, Metcalf BS, Jeffery AN, Frémeaux AE, Wilkin TJ. Metabolic risk in contemporary children is unre- lated to socio-economic status: longitudinal study of a UK urban population (EarlyBird 42). Pediatr Diabetes. 2014; 15:244-51. doi: $10.1111 /$ pedi.634

33. Skrede T, Stavnsbo M, Aadland E, Aadland KN, Anderssen SA, Resaland GK. Moderate-to-vigorous physical activity, but not sedentary time, predicts changes in cardiometabolic risk factors in 10-y-old children: the Active Smarter Kids Study. Am J Clin Nutr. 2017;105:1391-8. doi: 10.3945/ajen.116. 150540

34. Kolsgaard ML, Joner G, Brunborg C, Anderssen SA, Tonstad $\mathrm{S}$, Andersen LF. Reduction in BMI z-score and improvement in cardiometabolic risk factors in obese children and adolescents. The Oslo Adiposity Intervention Study - a hospital/public health nurse combined treatment. BMC Pediatr. 2012;12:77. doi: 10.1186/1471-2431-12-77

35. Rijks JM, Plat J, Mensink RP, Dorenbos E, Buurman WA, Vreugdenhil AC. Children with morbid obesity benefit equally as children with overweight and obesity from an ongoing care program. J Clin Endocrinol Metab. 2015;100:3572-80. doi: 10.1210/jc.2015-1444

Sažetak

\title{
KARDIOMETABOLIČKI RIZIK U GRADSKE DJECE U CRNOJ GORI - POVEZANOST S PRETILOŠĆU I SPOLOM
}

\author{
M. Martinović, G. Belojevic, M. Jakšić, N. Kavarić i A. Klisić
}

Imajući u vidu oprečne podatke iz literature, cilj našega istraživanja je bio ispitati utjecaj spola i pretilosti na kardiometabolički rizik (KMR) kod gradske djece u Crnoj Gori. Studija presjeka je obuhvatila slučajni uzorak od 201 učenika u dobi od 7-12 godina (64\% dječaci) iz Podgorice. Nutritivni status djece procijenjen je prema kriterijima International Obesity Task Force. KMR je izračunat kao zbir z vrijednosti dobivenih zbrajanjem 5 parametara: glukoze, ukupnog kolesterola, inverzne koncentracije kolesterola u lipoproteinima visoke gustoće, triglicerida i visokog krvog tlaka. Pretili i debeli dječaci su imali veći KMR u usporedbi s normalno uhranjenim dječacima ( $p<0,001)$. Ova razlika u KMR bila je manje izražena kod pretilih i debelih djevojčica $(p<0,05)$ u usporedbi s normalno uhranjenim djevojčicama. Logistička regresija je pokazala da je indeks tjelesne mase nezavisan prediktor povećanog KMR [OR=1,06; (95\% CI=1,02-1,10), p=0,002]. Nasuprot tome, nismo utvrdili utjecaj socio-ekonomskog statusa, fizičke aktivnosti ili sedentarnog načina života na povećan KMR u ispitivanoj kohorti djece. U zaključku, postoji povezanost pretilosti i KMR čak i u dječjoj populaciji, ali je taj učinak izraženiji kod dječaka u usporedbi s djevojčicama.

Ključne riječi: Kardiometabolički rizik; Pretilost u djece; Hipertenzija; Metabolički sindrom 